\title{
Ship speed optimization: Concepts, models and combined speed-routing scenarios
}

\author{
Psaraftis, Harilaos N.; Kontovas, Christos A.
}

Published in:

Transportation Research. Part C: Emerging Technologies

Link to article, DOI:

10.1016/j.trc.2014.03.001

Publication date:

2014

Document Version

Peer reviewed version

Link back to DTU Orbit

Citation $(A P A)$ :

Psaraftis, H. N., \& Kontovas, C. A. (2014). Ship speed optimization: Concepts, models and combined speedrouting scenarios. Transportation Research. Part C: Emerging Technologies, 44, 52-69. https://doi.org/10.1016/j.trc.2014.03.001

\section{General rights}

Copyright and moral rights for the publications made accessible in the public portal are retained by the authors and/or other copyright owners and it is a condition of accessing publications that users recognise and abide by the legal requirements associated with these rights.

- Users may download and print one copy of any publication from the public portal for the purpose of private study or research.

- You may not further distribute the material or use it for any profit-making activity or commercial gain

- You may freely distribute the URL identifying the publication in the public portal 


\title{
Ship speed optimization: concepts, models and combined speed-routing scenarios
}

\author{
Harilaos N. Psaraftis ${ }^{1}$ \\ and Christos A. Kontovas \\ Department of Transport, \\ Technical University of Denmark \\ Lyngby, Denmark \\ 27 February 2014
}

\section{Abstract}

The purpose of this paper is to clarify some important issues as regards ship speed optimization at the operational level and develop models that optimize ship speed for a spectrum of routing scenarios in a single ship setting. The paper's main contribution is the incorporation of those fundamental parameters and other considerations that weigh heavily in a ship owner's or charterer's speed decision and in his routing decision, wherever relevant. Various examples are given so as to illustrate the properties of the optimal solution and the various trade-offs that are involved.

KEY WORDS: Green maritime logistics; ship speed optimization; ship routing.

\section{Introduction}

In recent years, increasing fuel prices, depressed market conditions and environmental issues as regards air emissions from ships have brought a new perspective to ship speed. If this perspective had not received much emphasis in the past, this is not so today, and it will receive even more attention in the future. In addition to being efficient from an economic perspective, a ship also has to be environmentally friendly as regards air emissions. To that end, significant regulatory activity is already taking place within the International Maritime Organization (IMO) and other bodies. Such activity aims to cover the whole range from technical to operational to market-based measures and a wide spectrum of emissions, from greenhouse gases (GHGs) such as carbon dioxide $\left(\mathrm{CO}_{2}\right)$, to non-GHG gases such as sulphur oxides $\left(\mathrm{SO}_{\mathrm{x}}\right)$, nitrogen oxides $\left(\mathrm{NO}_{\mathrm{x}}\right)$, particulate matter $(\mathrm{PM})$ and others.

Because of the non-linear relationship between speed and fuel consumption, it is obvious that a ship that goes slower will emit much less than the same ship going faster. It that sense, the impact of a change in ship speed on both ship operating costs and emissions can be quite dramatic. This can be manifested at two levels, the design level and the operational level.

At the design level, Maersk's new 18,000 TEU 'Triple-E'2 containerships have a design speed of 17.8 knots, down from the 22 - 25 knots range that has been

\footnotetext{
${ }^{1}$ Corresponding author. Email: hnpsar@transport.dtu.dk
} 
the industry's norm, and will emit $20 \%$ less $\mathrm{CO}_{2}$ per container moved as compared to the Emma Maersk, previously the world's largest container vessel, and $50 \%$ less than the industry average on the Asia-Europe trade lane (Maersk, 2013).

At the operational level, the practice of reducing speed as a response to depressed market conditions and/or high fuel prices is known as "slow steaming", and is being practised in almost every commercial ship sector these days, including tankers, bulk carriers and containerships. In its simplest form, slow steaming may involve just slowing down vis-à-vis a vessel's design speed. However, speeds cannot be reduced below a certain threshold, as the ship's main engine may stall. Higher speed reductions can be achieved in modern, electronically-controlled engines than in older, camshaft-controlled engines. In order that slower speeds can be attained, it may be necessary to 'derate' the engine, that is, reconfigure the engine so that a lower power output is achieved, Such a reconfiguration may involve dropping one or more cylinders from the main engine or other measures. Depending on engine technology, 'slow steaming kits' are provided by engine manufacturers so that ships can smoothly reduce speed at any desired level. In case speed is drastically reduced, the practice is known as "super slow steaming".

In practice, super slow steaming has been pioneered by Maersk Line after it initiated trials involving 110 container vessels beginning in 2007. These trials showed that it was safe to reduce the engine load to as low as $10 \%$, compared with the traditional policy of reducing the load to no less than $40 \%-60 \%$ (Tradewinds, 2009). Given the non-linear relationship between speed and power, for a containership a 10\% engine load means sailing at about half of the design speed. Slow steaming is also being practiced in other shipping markets.

In addition to being important from an economics perspective, speed reduction can also have important environmental benefits, as emissions from ships are directly proportional to fuel burned. In that sense, speed reduction is one of the important operational or logistics-based measures to reduce emissions from ships.

The purpose of this paper is to clarify some important issues as regards ship speed optimization at the operational level and to develop models that optimize ship speed for a spectrum of ship routing scenarios and for several variants that concern the objective function to be optimized. Its main contribution vis-a-vis the state of the art is the incorporation of those fundamental parameters and other considerations that weigh the most in a ship owner's or charterer's speed decision at the operational level and also in his routing decision, wherever relevant. These are (a) the fuel price, (b) the state of the market (freight rate), (c) the inventory cost of the cargo, and (d) the dependency of fuel consumption on payload. To do so, the paper goes over various examples so as to illustrate the properties of the optimal solution and the various trade-offs that are involved.

\footnotetext{
${ }^{2}$ Triple-E stands for Economy of scale, Energy efficiency and Environmentally improved performance.
} 
The rest of this paper is organized as follows. In section 2 we discuss modeling approaches for this class of problems, including assumptions, simplifications and possible misconceptions. In section 3 we list the scenarios and problem variants examined in the paper. In section 4 we discuss some properties of the optimal solution, including some that are counter-intuitive. Finally in section 5 we present the paper's conclusions. An Appendix describes the algorithm used for one of the examples in the paper.

\section{Modeling approaches: assumptions, simplifications and possible misconceptions}

\subsection{Treatment of speed in the literature}

Before we deal with ship speed problems, we cite a parallel body of research in road transportation, in which vehicle speed is a decision variable that impacts various attributes including cost and emissions. See for instance Figliozzi (2010), Bektas and Laporte (2011), Erdoğan and Miller-Hooks (2011), Özceylan et al. (2011) and Kopfer and Kopfer (2013). In these papers, economic and environmental trade-offs among several objective functions are examined, in case vehicle speed is constant or variable. The main difference with a maritime setting is the form of fuel consumption function, which in the road setting is a function of road profile, driver behavior, and other factors that are not relevant in shipping. However from an optimization viewpoint it is clear that some of the techniques used can be very relevant (eg, neighborhood search).

As regards maritime transportation, the first observation is that many of the OR/MS models found in the literature assume fixed and known speeds for the ships. See for instance Rana and Vickson (1991), Agarwal and Ergun (2008), Hwang et al (2008), Grønhaug et al (2010) and Song and Xu (2012), among others. In these models, ship speed is typically considered not as a decision variable but as an input to the problem. Most of the time this input is implicit, in the sense that it is used to compute various other explicit inputs that depend on speed, such as sailing times, due dates for cargo pickup and delivery, and ship operating costs, of which fuel costs are an important component.

However, not including speed as a decision variable may render solutions subobtimal. This is so because generally there are important economic tradeoffs between (a) the lower charter and cargo inventory costs associated with a higher speed and (b) the higher fuel costs associated with such higher speed. Assuming a fixed speed precludes the balancing of such trade-offs. A speed that is assumed fixed may also in some cases remove flexibility in the overall decision making process. For problems that include port capacity constraints, berth occupancy constraints, time window constraints or other constraints that preclude the simultaneous service of more than a given number of vessels, satisfying such constraints would conceivably be easier to meet were it not for the assumed constancy in ship speed.

Assuming fixed ship speeds is typically also the case for models that compute shipping emissions worldwide, even though typically these do not belong to the 
OR/MS literature. See for instance IMO (2009) and Psaraftis and Kontovas (2009), among others. In their calculations, these models typically take as input design speeds extracted from commercially available ship databases, such as those maintained by IHS Fairplay, among others.

Still, dealing with speed is not new in the maritime transportation literature and this body of knowledge is rapidly growing. In Psaraftis and Kontovas (2013) some 40 relevant papers were reviewed and a taxonomy of these papers according to various criteria was developed.

As in other areas, most OR/MS papers that deal with ship speed consist of two basic steps: (A) the formulation of an optimization model, followed by (B) the design and testing of an algorithm, exact or heuristic, that solves the optimization problem associated with the model. Both steps (A) and (B) are important. Much as it would not make sense to develop an algorithm or method that is inferior to the state-of-the art, it would also not make sense to formulate a model that does not map reality in a reasonably realistic way. The latter would render any possible advances in step (B) less meaningful. For these reasons one would expect a balanced treatment of both steps (A) and (B).

Yet, in our literature search, we found that for this category of problems, much of the focus is more on step (B) and less on step (A). Perhaps this is natural to be expected, particularly given the methodological emphasis of many of the relevant journals. However, and in all fairness to step (A), we shall attempt to highlight in the rest of this section some typical modeling approaches that have been or are being pursued in the literature and some of which in our opinion may create some misconceptions and possibly lead to suboptimal solutions. These pertain to modeling assumptions, simplifications, or otherwise treatment of (i) form of fuel consumption function, (ii) fuel price, (iii) state of the market, (iv) in-transit inventory costs, and (v) mixed chartering scenarios.

\subsection{Form of fuel consumption function}

There are a variety of issues that come at play here.

\subsubsection{Cubic functions}

Many papers that do embed ship speed in their formulation assume that daily fuel consumption is a cubic function of ship speed. The cubic approximation is reasonable for some ship types, such as tankers, bulk carriers, or ships of small size, but may not be realistic at slow or near-zero speeds and for some other ship types such as high-speed large container vessels. Even at zero speed the ship consumes some fuel, as its auxiliary engines are typically on to produce electricity (an exception is if electricity is provided to the ship by shore-side supply, but this is currently an exception rather than the rule). In-port fuel consumption is proportional to overall total port residence time.

\subsubsection{Dependency on payload}


A more serious assumption in many papers is that no dependency between fuel consumption and ship payload is considered. This can cause serious under- or over-estimation of fuel costs, because ship resistance and hence fuel consumption at a given speed can be drastically different if the ship is full, empty or at an intermediate loading condition. In tankers and bulk carriers we have a 'binary' situation as the ship is typically either full or empty, and the difference in fuel consumption between these two extreme conditions can be quite substantial. In container vessels the ship is typically intermediately laden, but ships in some trunk routes (eg Far East to Europe) are mostly full in one direction and mostly empty in the opposite. This is close to a binary situation and one would expect non-trivial differences in fuel consumption as well. Similar considerations pertain to all ships. In general, if a ship's loading condition varies along the legs of a ship's route (which is typical in pickup and delivery scenarios in which the ship is not fully laden all the time), it is important that the dependency between ship load and fuel consumption along that route be realistically modeled. It would not make sense to obtain solutions within, say, 1,2 or $5 \%$ from the 'optimum', or even at the exact 'optimum', if the fuel consumption function is misrepresented by 10,20 or $30 \%$.

In sailing from port A to port B, whoever is paying for the fuel (the ship owner or the charterer) can select the ship's sailing speed on that leg. In that selection, the decision maker is constrained by the ship's contractual obligations for the trip and by the ship's hydrodynamic and power characteristics. Within these constraints, there may be considerable latitude for choosing an appropriate speed, depending on the objective to be optimized.

\section{VLCC}

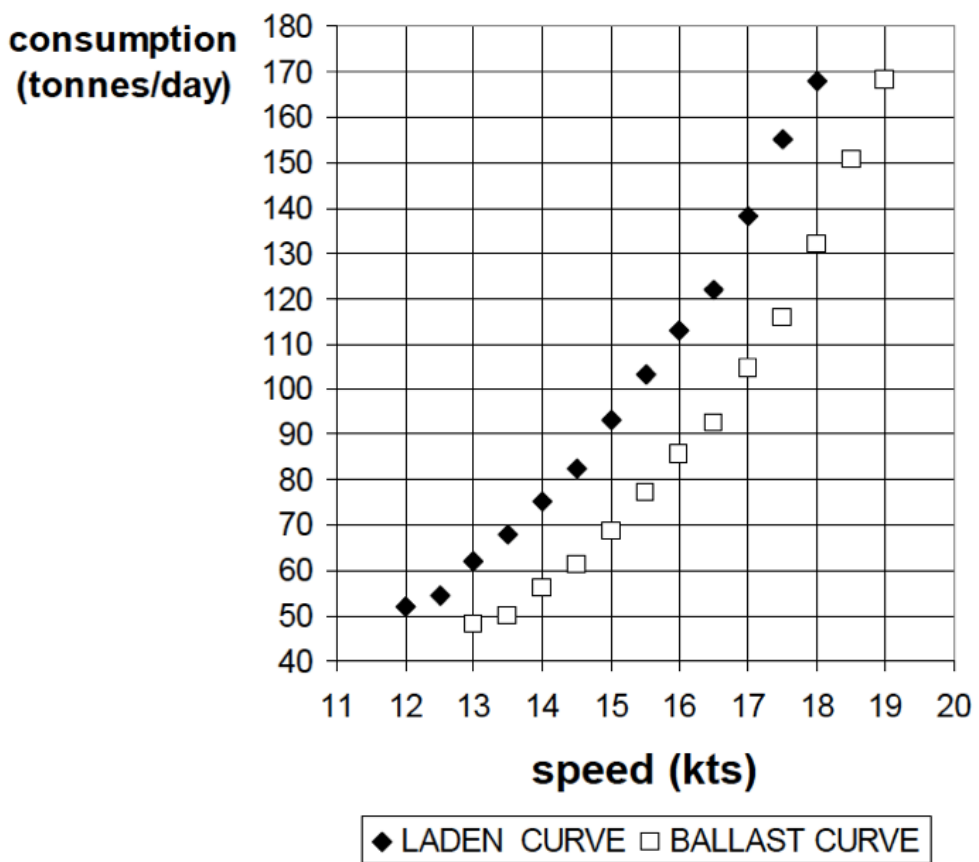

Figure 1: Typical fuel consumption functions for a VLCC. Source: Gkonis and Psaraftis (2012). 
It is known from basic naval architecture that fuel consumption depends nonlinearly on both ship sailing speed and ship payload. In order to capture this dependency, it is useful to assume that the daily 'at-sea' fuel consumption of a ship sailing from port $A$ to port $B$ is a known function $f(v, w)$ of both $v$, the ship's speed from $A$ to $B$, and $w$, the ship's payload from $A$ to $B$. Function $f(v, W)$ depends on the ship, and essentially on the geometry-engine-propeller combination. It can even be defined for $w=0$ (ship going on ballast), and it need not be assumed in closed form, but could be given as a pointwise function or even as the output of a relevant subroutine ${ }^{3}$. Figure 1 shows such a function for a Very Large Crude Carrier (VLCC) for the laden and ballast conditions, solicited and obtained from a tanker shipping company; see also Gkonis and Psaraftis (2012). It can be seen that the difference between laden and ballast fuel consumption at the same speed is on the order of $25-30 \%$.

A realistic closed-form approximation of $f$ that takes both $v$ and $w$ into account is $f(v, w)=k\left(p+v^{q}\right)(w+A)^{2 / 3}$ with $k, p$ and $q$ constants such as $k>0, p \geq 0$ and $q \geq 3$, and $A$ is the 'lightship weight', that is, the weight of the ship if empty including fuel and other consumables (modified admiralty formula). The rationale for such a formulation is that fuel consumption is proportional to the wetted surface of the ship, which is crudely proportional to the displacement of the ship $(w+A)$ raised to the power of 2/3; see also Barrass (2005). As said earlier, most papers in the literature assume a cubic function, that is, $p=0$ and $q=3$ and no dependency on payload.

\subsubsection{Other factors that may impact fuel consumption}

The fuel consumption function depends on some additional important factors, such as the prevailing weather conditions. The way weather conditions are treated in the literature ranges from non-treatment (implying that the average weather conditions the ship expects along its route are implicitly factored into the function $f$, perhaps by a 'sea margin' coefficient), to more sophisticated approaches in which $f$ depends on the specific weather conditions along the ship's route, including wave height, wave direction, wind speed, wind direction, sea currents, and possibly others. These factors can significantly influence both wave and wind resistance and hence fuel consumption and cost. Weather routing models typically take the latter approach, with all other OR/MS models including ship routing and scheduling, fleet deployment, and other models following the former.

Hull condition can also be an important factor that influences the frictional resistance of a ship, and, as a result, its fuel consumption. A foul hull from seaweed and other sea organisms would entail a higher resistance (and hence fuel consumption) than a clean hull, and efforts are being made (via anti-fouling paints and hull cleaning at regular intervals) to maintain a clean hull. To our knowledge, no OR/MS model takes into account such factor, all assuming an average hull condition.

\footnotetext{
${ }^{3}$ Strictly speaking, $f$ must take into account the reduction in the ship's total displacement due to fuel being consumed along the ship's route. However, since displacement would not change much as a result of that consumption, one can practically assume findependent of en-route fuel consumption.
} 


\subsection{Fuel price}

It is obvious that fuel prices are a very critical determinant of fuel costs, and, as such, of the speed chosen by the vessel. In fact fuel price is the one of two main factors that play a critical role in the determination of ship speed (the state of the market being the other one, see section 2.4). Containership speeds of up to 33 knots in the late 60 s are nowhere to be seen these days, and the main reason is the significant increase of fuel prices.

All OR/MS models that we have reviewed incorporate fuel prices as part of their input. However, in many models such inclusion is only implicit, whereas in others it is explicit. An implicit formulation (for instance a fuel cost function $c(v)$ of speed $v$ ), means that the fuel price is not explicitly part of the problem's input. An implicit formulation has the drawback of not allowing someone to directly analyse the functional dependency between fuel price and vessel speed, which can be very important.

\subsection{State of the market}

Another modeling assumption that is reflected in several OR/MS models that deal with ship speed is that these models do not include the state of the market (spot rate, or other freight rate) as part of their formulation. It is well known in shipping that an important tradeoff in pursuit of higher profits for a ship owner is the balance between more trips and hence more income at a higher speed and less trips because the cost of fuel is high. This is so when the ship is on spot charter, in which case the fuel is paid by the ship owner. While on spot charter, the owner would like to take advantage of high freight rates by hauling as much cargo as possible within a given period of time. Conversely, if the market is low, ships tend to reduce speed, as the additional revenue from hauling more cargo is less than the additional cost of the fuel. The main reason for slow steaming these days is the depressed state of the market.

It is not often realized that such behavior is also relevant for the charterer, if the ship is on time or bareboat charter. The objective of the charterer is to minimize costs, including fuel costs, which are paid by the charterer for these types of contract. If the market is high, the charterer may want to speed up so as to pay less for time chartering the ship, or even conceivably charter out extra capacity. Whether owner or charterer, not factoring in the state of the market in a speed model means that the model may not be able to capture one of the fundamental facets of shipping industry behavior, according to which the state of the market, along with the price of fuel, are two main determinants of the speed of vessels.

Given that ship speeds are anything but predetermined, those who pay for the fuel, that is, the ship owner if the ship is on spot charter, or the charterer if the ship is on time or bareboat charter, will typically choose a speed that optimizes their objective, be that profit in the case of a ship owner, or cost in the case of the charterer. As shown in Devanney (2010), in case costs or profits are expressed on an average per day basis, and even though the two optimization problems (that of the ship owner and that of the charterer) may seem at first 
glance different, in fact they turn out to be mathematically the same. The same is true for the corresponding optimal speeds.

As shown in Psaraftis and Kontovas (2013), and as is also widely known in the shipping industry, the nondimensional ratio of (fuel price/spot rate) is a key determinant of whether the ship will speed up or slow down. The higher that ratio is, the lower the optimal speed of the ship will be, assuming of course that speed is allowed to be chosen and is not fixed by contractual agreement.

\subsection{In-transit cargo inventory costs}

Another observation is that many of the reviewed speed models do not include in-transit inventory costs as part of the cost function. These are inventory costs that accrue while the ship is in transit, and they can be a non-trivial component of the cost that the owner of the cargo bears if the ship will sail at a reduced speed. They can be important if timely delivery of the cargo is significant. They can also be important if the voyage time and/or the quantities to be transported are non-trivial ${ }^{4}$.

Cargo inventory costs can be important in the liner business which involves trades of higher valued goods than bulk trades. The unit value of the top 20 containerized imports at the Los Angeles and Long Beach Ports in 2004 varied from about $\$ 14,000 /$ tonne for furniture and bedding to $\$ 95,000 /$ tonne for optic, photographic and medical instruments (CBO, 2006). Delaying one tonne of the latter category of cargo by one week because of reduced speed would cost some $\$ 91$ if the cost of capital is $5 \%$. For a 80,000 tonne payload this would amount to some $\$ 7.25$ million. This may or may not be greater than the economic benefit of a reduced speed.

But the liner market is not the only one in which inventory costs are important. Fig. 2 below, from Gkonis and Psaraftis (2012), shows that optimal ship speeds vary, depending on whether or not in-transit inventory costs are taken into account. Including that cost component would generally increase the optimal speed. The example is for a VLCC. It can be seen that whereas if no inventory costs are factored in ballast speeds are uniformly above laden speeds, in case inventory costs are factored in this is not necessarily the case. In the example, one can observe that if fuel (HFO) prices are higher than about USD 600/tonne (a break even price), optimal laden speeds are higher than the equivalent ballast speeds.

\footnotetext{
${ }^{4}$ This can be the case in long-haul problems.
} 


\section{SPOT RATE WS100}

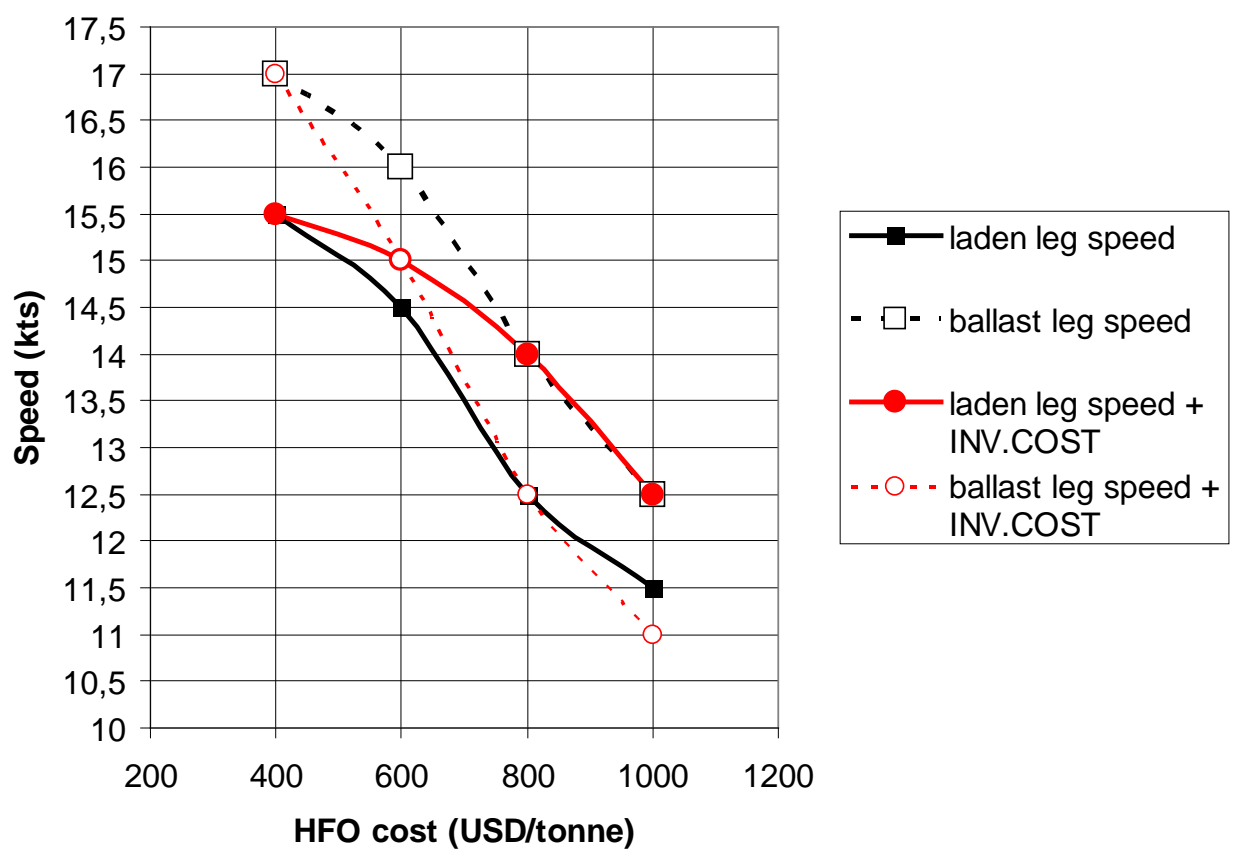

Figure 2: Optimal VLCC speeds with and without inventory costs. Source: Gkonis and Psaraftis (2012)

Somebody then may wonder, if the speed optimizer is the ship owner (situation pertaining to spot chartering) and not the charterer, assuming the latter is also the owner of the cargo, why are in-transit inventory costs important? For one thing, these costs are borne by someone else, the charterer, and not the ship owner. They are important because everything else being equal, a charterer will prefer a ship that delivers his cargo earlier than another ship that sails slower, and if the owner of the latter ship would like to attract that cargo he may have to rebate to the charterer the loss due to delayed delivery of cargo. In that sense, the in-transit inventory cost is very much relevant in the ship owner's profit equation (as much as it is relevant in the charterer's cost equation).

The same is the case if the charterer does not move his own cargo but uses the ship to move somebody else's cargo. This is a typical situation in liner trades, where a significant part of a liner company's fleet consists of chartered ships, owned by independent ship owners but operated by the liner company. As the cargo owner will prefer a ship that moves his cargo faster, his in-transit inventory costs are again very much part of the chartered ship's cost equation.

Mathematically, the per day in-transit inventory cost of a tonne of cargo is $P R / 365$, where $P$ is the CIF value of the cargo and $R$ the cargo owner's cost of capital. This represents the revenue that is lost due to delayed delivery of one tonne of the cargo by one day. This means (as expected) that expensive cargoes are more costly than cheaper cargoes in terms of inventory cost. This also explains why expensive cargoes tend to get hauled by liner ships that go faster, whereas cheaper (bulk) cargoes go by tramp ships that go slower. 
Conversely, it also means that in periods of low interest rates this cost component is less important. We shall come back to this point later.

\subsection{Mixed chartering scenarios}

There are a number of combined ship speed optimization and routing papers in the OR/MS literature that assume a 'mixed' chartering scenario (see for instance Fagerholt and Ronen (2013)). In the mixed scenario, a number of the cargoes are labeled 'mandatory' cargoes, to be moved under COA (contract of affreightment) terms, and the rest are 'optional' cargoes, to be moved under spot charter terms. The word optional here means that the spot cargoes would generate additional revenue for the ship owner, who has the option whether or not to embed these cargoes within his service plan, in addition to the mandatory cargoes, whose revenue is considered fixed and therefore does not impact the optimization problem. Given this additional potential revenue from the optional spot cargoes, it may make sense for some ships in the fleet to pick up some of these cargoes along the route. It may also make sense for the ships to sail at a higher speed in order to accommodate these optional cargoes and not violate time window constraints that may exist for the mandatory cargoes.

A number of points can be made for such scenarios. The first is on the distinction between mandatory and optional cargoes. It is clear that any cargo, including the COA cargoes, is optional until the ship owner and the charterer decide to enter into a mutually binding contract for that cargo. After contract signature, serving the cargo in question becomes mandatory. The same is true for the spot cargoes; they are only optional until an agreement to carry them is reached. Of course, the timing of contract signature for these two types is different, that of the COA preceding that of the spot cargoes.

A related issue that is sometimes not mentioned but may further complicate things is that the owner who has signed a COA will have to obtain the permission of the COA charterer to serve additional spot cargoes. This may involve amending the COA itself, not necessarily an easy proposition. The permission of the COA charterer may be warranted because adding spot cargoes may imply delayed delivery of the COA cargoes and also may involve liability issues, for instance if the ship (together with the COA cargoes) is lost or damaged in case the spot cargoes are dangerous or semi-dangerous.

It is known that a COA does not require a ship owner to name a ship at the time of contract signature. But as the contract will specify the size of the shipments, the size of the ships that will carry them under the COA is likely to be more or less indirectly implied, usually leaving little or no extra space for spot cargoes. Of course, fulfilling the COA with ships larger than required so as to allow for spot cargoes is an important option. But this implies that the decision which ships to assign for the COA is made simultaneously with the decision which spot cargoes to serve. Assigning larger ships for the COA before potential spot cargoes are known may entail a financial risk and a potential loss to the ship owner. Even though many papers in this area also deal with uncertainty, we have seen no models that try to capture this specific risk as part of their formulation. 
Irrespective of the above, in mixed scenarios such as this, ship payload will generally vary along the ship's route. Note however that, to our knowlege, all papers in the literature that deal with such mixed scenarios assume a fuel consumption function independent of ship payload. For reasons outlined earlier, this may misrepresent the fuel costs along the route and hence may lead to suboptimal solutions.

Table 1 below lists a limited sample of related papers in the literature, covering various logistical contexts, with respect to whether or not (a) fuel consumption is a function of payload, (b) fuel price is an explicit or implicit input, (c) freight rate is an input, and (d) cargo inventory cost is taken onboard. Various combinations of (a) to (d) can be seen. For more details on papers in the table that are not already cited previously in this paper see Psaraftis and Kontovas (2013).

Table 1: sample of papers according to criteria (a) to (d)

\begin{tabular}{|c|c|c|c|c|c|}
\hline $\begin{array}{l}\text { Papers (listed } \\
\text { chronologically) }\end{array}$ & $\begin{array}{l}\text { Logistical } \\
\text { context }\end{array}$ & $\begin{array}{l}\text { Fuel } \\
\text { consumption } \\
\text { a function of } \\
\text { payload? }\end{array}$ & $\begin{array}{l}\text { Fuel price } \\
\text { explicit or } \\
\text { implicit } \\
\text { input? }\end{array}$ & $\begin{array}{l}\text { Freight } \\
\text { rate an } \\
\text { input? }\end{array}$ & $\begin{array}{l}\text { Cargo } \\
\text { inventory } \\
\text { cost taken } \\
\text { onboard? }\end{array}$ \\
\hline Ronen (1982) & $\begin{array}{l}\text { Tramp fixed } \\
\text { route }\end{array}$ & No & Explicit & Yes & No \\
\hline $\begin{array}{l}\text { Perakis \& } \\
\text { Jaramillo (1991) }\end{array}$ & $\begin{array}{l}\text { Liner fleet } \\
\text { deployment }\end{array}$ & No & Explicit & Yes & No \\
\hline $\begin{array}{l}\text { Devanney } \\
(2007)\end{array}$ & $\begin{array}{l}\text { World oil } \\
\text { network } \\
\text { model }\end{array}$ & $\begin{array}{l}\text { Only for } \\
\text { laden and } \\
\text { ballast } \\
\text { conditions }\end{array}$ & Explicit & $\begin{array}{l}\text { Equilibrium } \\
\text { spot rate } \\
\text { computed }\end{array}$ & Yes \\
\hline $\begin{array}{l}\text { Notteboom \& } \\
\text { Vernimmen } \\
(2010)\end{array}$ & $\begin{array}{l}\text { Container } \\
\text { fixed route }\end{array}$ & No & Explicit & No & No \\
\hline $\begin{array}{l}\text { Norstad et al } \\
\text { (2011) }\end{array}$ & $\begin{array}{l}\text { Tramp } \\
\text { pickup and } \\
\text { delivery }\end{array}$ & No & Implicit & No & No \\
\hline $\begin{array}{l}\text { Cariou \& } \\
\text { Cheaitou (2012) }\end{array}$ & $\begin{array}{l}\text { Container } \\
\text { fixed route }\end{array}$ & No & Explicit & No & Yes \\
\hline $\begin{array}{l}\text { Gkonis \& } \\
\text { Psaraftis (2012) }\end{array}$ & $\begin{array}{l}\text { Tanker fixed } \\
\text { route }\end{array}$ & $\begin{array}{l}\text { Only for } \\
\text { laden and } \\
\text { ballast } \\
\text { conditions }\end{array}$ & Explicit & Yes & Yes \\
\hline $\begin{array}{l}\text { Hvattum et al } \\
\text { (2013) }\end{array}$ & Fixed route & No & Implicit & No & No \\
\hline $\begin{array}{l}\text { Fagerholt \& } \\
\text { Ronen (2013) }\end{array}$ & $\begin{array}{l}\text { Bulk ship } \\
\text { routing, } \\
\text { mixed } \\
\text { chartering } \\
\text { scenario }\end{array}$ & No & Implicit & $\begin{array}{l}\text { Only for } \\
\text { spot } \\
\text { cargoes }^{5}\end{array}$ & No \\
\hline This paper & $\begin{array}{l}\text { Fixed or } \\
\text { flexible route }\end{array}$ & $\begin{array}{l}\text { For any } \\
\text { loading } \\
\text { condition }\end{array}$ & Explicit & Yes & Yes \\
\hline
\end{tabular}

\section{Scenarios and problem variants}

\footnotetext{
${ }^{5}$ A known revenue is assumed for each of the spot cargoes, implying a freight rate for them.
} 
The speed models examined in this paper deal with a single ship and can be used in several logistical scenarios. By increasing order of complexity, these include:

- Fixed-route scenarios: A ship going from A to B, or even on a multiple leg route in which the sequence of port visits is already determined but ship payload varies along the route. It is assumed that the route has already been determined at a higher level.

- Feeder scenarios: A feeder ship collecting cargoes from several ports and bringing them into a hub port or vice versa.

- Combined pickup and delivery scenarios: A ship picking up cargoes from distinct origins and delivering them to distinct destinations.

The latter scenario is actually a generalized version of the feeder scenario and includes several sub-scenarios itself, depending on whether each port has one or multiple pickup cargoes, to be delivered to one or several delivery ports.

Whatever the scenario, we are given a set of ports $N=\{0,1,2, \ldots, n\}$. Inter-port distances are known and equal to $s_{i j}(i \in N, j \in N)$, in nautical miles. Also we are given an origin/destination (O/D) matrix $\left[d_{i j}\right]$, representing the weight of cargo that has to go from port $i$ to port $j(i \in N|O, j \in N| O, i \neq j)$, in tonnes. This matrix is not necessarily symmetric. So we assume that the set of cargoes is fixed and that each cargo is considered a distinct commodity and cannot be split.

In all scenarios the ship is assumed to be initially located at port 0 (home port), and has to: (a) pick up from each port the cargoes destined to other ports, (b) deliver to each port the cargoes originating from other ports, and, optionally, depending on the scenario, (c) return to port 0 . Ship capacity is $Q$ and cannot be exceeded. It is assumed that $Q \geq \max (i, j) d_{i j}$, otherwise the problem is infeasible.

In all scenarios we need to decide on the appropriate sailing speeds for each leg of the route, as well as the route itself, if the latter is not fixed.

The chartering context assumed is that of a time charter. Time charters constitute the majority of contracts in maritime transportation. They involve the rental of the ship for a specified period. The decision maker in all these cases is assumed to be the charterer. This is the effective owner of the vessel during the duration of the charter (in shipping parlance this is known as the 'disponent owner').

Who owns the cargoes in our scenario? The default assumption is that the charterer of the ship is also the cargo owner. This would be the case whenever an oil company, chemical company, bulk cargo company or other industrial company charters the ship on time charter for a specified duration, so as to carry its own cargoes.

However, one can also examine the case in which the charterer does not have cargoes of his own and uses the ship to move someone else's cargo or 
cargoes. This case would involve revenue from the cargo owner(s) to the charterer, but if the set of cargoes to be moved is assumed fixed, the associated revenue is a constant and does not enter the optimization problem. Using ships in such a fashion is not uncommon in tramp shipping (ships are known as 'relets'), and in fact it is rather common in liner shipping, where ships are owned by independent owners and chartered to a liner company, who is the effective operator of these ships, so as to move cargoes that belong to third parties.

In all cases, the charterer would like to minimize the total cost of the trip, which has the following three components: (a) fuel cost, (b) time charter cost, and (c) cargo inventory cost, as further elaborated below.

Fuel cost: Since in a time charter the charterer pays for the fuel, a basic tradeoff for the charterer is whether he should complete the trip as soon as possible, so as to reduce the charter paid to the ship owner (see below), or go slower so as to reduce fuel cost. Fuel is assumed to be purchased at a known fuel price of $P_{\text {FUEL }}$ (\$/tonne). The default scenario ignores port-related costs to be borne by the charterer, even though including these costs is a straightforward extension (see Appendix).

The daily at sea fuel consumption of the ship sailing from $i$ to $j$ is equal to $f\left(v_{i j}\right.$, $\left.w_{i j}\right)$ (tonnes/day), which is assumed a known function of the ship's speed $v_{i j}$ and payload $w_{i j}$ from $i$ to $j$. Function $f$ can even be defined for $w_{i j}=0$ (ship going on ballast). In-port fuel costs are assumed proportional to overall total port residence time, but as the latter is a constant proportional to total cargo moved, they can be ignored.

In general, different speeds can be chosen for different legs of the route, so long as they are within the speed window $\left[v_{L B}\left(w_{i j}\right), v_{U B}\left(w_{i j}\right)\right]$, where $v_{L B}\left(w_{i j}\right)$ and $V_{U B}\left(W_{i j}\right)$ are lower and upper bounds (respectively) on the speed. Both bounds are dictated by the maximum power and technology of the engine, and by $w_{i j}$, the ship's payload when sailing from $i$ to $j\left(0 \leq w_{i j} \leq Q\right)$. The upper bound exists because of limits in the ship's power and the lower bound exists because it is simply impossible for a ship engine to run lower than a certain power. For a given ship, both bounds depend on main engine size and technology.

Time charter cost: In a time charter, the charterer pays to the ship owner a known freight rate of $F$ (\$/day), with $F$ being an exogenous variable mainly determined by market conditions. It can be high in boom periods or low in depressed market periods. It is assumed that the time charter ends with the termination of the route and that the value of $F$ is independent of charter duration and is agreed upon before the voyage commences ${ }^{6}$.

Cargo inventory cost: The third component of the cost that we assume the charterer bears is the inventory cost of the cargo. Per earlier considerations (see section 2.5), we consider this cost irrespective of whether or not the

\footnotetext{
${ }^{6}$ The assumption that $F$ is independent of charter duration is valid if the charter duration is within a reasonably narrow range. For large variations of time charter duration (eg a few months versus a multi-year charter), we expect that $F$ will generally vary with charter duration.
} 
charterer is the cargo owner. We assume that the per unit volume and per unit time cargo inventory cost is equal to $\alpha$ for cargo awaiting to be picked up (cost accrues from time 0 until cargo is on the ship) and to $\beta$ for cargo within the ship (cost accrues from time cargo is on the ship until cargo is delivered). In that sense, $\beta$ corresponds to the in-transit inventory cost. Both $\alpha$ and $\beta$ are constants (\$/tonne/day), and both are non-negative.

Coefficients $\alpha$ and $\beta$ may be different for various reasons. For instance, the case $\alpha=0$ assumes that cargo is available at the loading port in a 'just-in-time' fashion and related waiting or delay costs are zero. Also, these costs would generally depend on whether the cargo is at the origin's warehouse or inside the ship. The case $\alpha=\beta=0$ means that inventory costs are insignificant or are ignored altogether.

It can be seen that even for each of the scenarios described earlier, several variants of the problem may exist, depending on the objective function. It turns out that these variants can be defined by an appropriate choice of the inputs.

The minimum trip time problem is tantamount to setting $P_{F U E L}=\alpha=\beta=0$ and leaving $F$ as the only nonzero cost coefficient.

At the other extreme, the minimum emissions problem is tantamount to setting $\alpha=\beta=F=0$ and leaving $P_{F U E L}$ as the only nonzero cost coefficient.

It is important to realize that different objective functions will generally produce different solutions, as will be seen in some examples that will be presented in the sections that follow.

\section{Properties of the optimal solution}

Interesting insights can be obtained by investigating properties of the optimal solution. These can be described in the sections that follow.

\subsection{Decomposition property}

Whatever the scenario, be it fixed route or flexible route, the first property is that the speed decision at each route leg can be decomposed from speed and (if applicable) routing decisions at subsequent route legs. Looking at an individual leg of the route, and assuming the ship is at port $L$ and wants to sail to the next port $L '$, the total cost on leg $(L, L)$ is equal to

$$
\cos T\left(L, L^{\prime}\right)=\left(P_{F U E} f(v, w)+\alpha u+\beta w+F\right) \cdot \frac{S_{L^{\prime}}}{v}
$$

with

v: ship speed during leg

w: ship payload during leg

$u$ : total weight of cargo not yet picked up while ship sails on leg 
This cost can be minimized with respect to speed $v$. As we can factor out the leg distance $S_{L L^{\prime}}$, the leg's optimal speed is the solution of the following problem:

$C^{*}=\min _{v \in S}\left\{\frac{P_{F U E L} f(v, w)+a u+\beta w+F}{v}\right\}$

with

$S=\left\{v: v_{L B}(w) \leq v \leq v_{U B}(w)\right\}$

$C^{*}$ is the minimum per mile cost of the leg. We note that it is independent of leg distance $s_{L L}$. In addition, and other than the fact that it depends on variables $w$ and $u$, which depend on the ship's entire route history up to $L$, this minimum per mile cost is also independent of either $L$ or $L^{\prime}$, that is, is independent of which is the route leg under consideration.

It is also important to realize that, in the absence of time windows, the speed decision on leg $\left(L, L^{\prime}\right)$ has no repercussion on subsequent routing or speed decisions, as it does not affect the subsequent values of the parameters $w$ or $u$ at port $L^{\prime}$. The speed decision on this leg depends on the values of $w$ and $u$ at port $L$, on the fuel price $P_{\text {FUEL }}$ and the charter freight rate $F$. It also depends on coefficients $\alpha$ and $\beta$, as well as the function $f$. Generally, high values for $F, \alpha$ and $\beta$ and/or low values for $P_{\text {FUEL }}$ would induce higher speeds than if the opposite is the case.

This means that, provided we know the parameters $w$ and $u$ at port $L$, the speed optimization problem for any specific leg can be solved in a stand-alone mode, the solution method depending on the form of function $f$. If a general form is given, the problem can be solved by complete enumeration, perhaps over a finite set of discrete speed values. As these results are not leg-specific, all of these calculations can be carried out in advance only once, and the results can even be tabulated in an appropriate parametric form and be ready for subsequent use. We note that this is true independent of the algorithm that is used for the routing part, be that exact or heuristic.

We can also explore special cases if a mathematical form is given for function $f$. Then a closed-form solution can be given.

As an example, assume that $f(v, w)=g\left(p+v^{q}\right)(w+A)^{2 / 3}$

with $g, p, q$ and $A$ known constants. This functional form realistically links $f$ with both ship speed and payload.

Then we want to minimize with respect to $v$ the function

$$
H(v)=\frac{P_{\text {FUE }}\left(g\left(p+v^{q}\right)(w+A)^{2 / 3}\right)+\alpha u+\beta w+F}{v}=k_{1} v^{q-1}+\frac{k_{2}}{v}
$$

with $k_{1}=P_{\text {FUEI }} g(w+A)^{2 / 3}$ 
and $k_{2}=P_{F U E I} g p(w+A)^{2 / 3}+\alpha u+\beta w+F$

Let $v^{*}=\left(\frac{k_{2}}{k_{1}(q-1)}\right)^{1 / q}$

(this is the speed that sets the 1st derivative of $H(v)$ equal to zero)

Note that $\frac{k_{2}}{k_{1}}=\frac{P_{F U E I} g p(w+A)^{2 / 3}+\alpha u+\beta w+F}{P_{F U E} g(w+A)^{2 / 3}}=p+\frac{\alpha u+\beta w+F}{P_{F U E I} g(w+A)^{2 / 3}}$

Then if $v_{L B}(W) \leq V^{*} \leq v_{U B}(W), v_{O P T}=V^{*}$

If $V^{*}<v_{L B}(W), v_{O P T}=v_{L B}(W)$

If $V^{*}>V_{U B}(W), V_{O P T}=V_{U B}(W)$

For the minimum emissions (or minimum fuel consumption) speed, one can set $\alpha=\beta=F=0$ and $H(v)$ is as follows:

$H(v)=\frac{C A R B \cdot P_{\text {FUEI }}\left(g\left(p+v^{q}\right)(w+A)^{2 / 3}\right)}{v}=C A R B \cdot P_{F U E I}\left[g\left(\frac{p}{v}+v^{q-1}\right)(w+A)^{2 / 3}\right](6)$

with CARB being the "carbon coefficient", tonnes of emissions per tonne of fuel burned. For $\mathrm{CO}_{2}$ emissions an approximate value of $C A R B$ is 3.11.

In this case $\frac{k_{2}}{k_{1}}=p \quad(=0$ if $f$ is cubic $)$ and $\quad v^{*}=(p(q-1))^{1 / q}$

For minimum emissions, quite likely $v_{O P T}=v_{L B}(W)$ (this is surely so if $f$ is cubic).

Another property concerns the possible impact of the freight rate and other input parameters on the optimal route and is discussed next.

From the above it can be seen that $F$ and other input parameters such as $P_{F U E L}, \alpha$ and $\beta$ can influence the speed decision at each leg. In particular, the optimal speed is a non-decreasing function of $\alpha, \beta$ and $F$, and a non-increasing function of $P_{F U E L}$. High rates, expensive cargoes and cheap fuels will induce higher speeds than low rates, cheaper cargoes and more expensive fuels.

As a parenthesis we note that such a property is also valid in a multiple ship setting. If which ship serves which set of cargoes and which route is known, and if the objective is the same as above for the fleet as a whole, a similar speed selection rationale should be applied for each of the ships in the fleet.

\subsection{Freight rate and other input parameters may influence the routing decision}

What is less obvious is that input parameters such as the above may also influence the routing decision. This is indeed the case and it can be shown by a rudimentary example as follows. 
A cargo ship of lightship weight equal to $A=5$ and capacity equal to $Q=11^{7}$, loads two cargoes of sizes 10 and 1 (all sizes in thousand tonnes) at hypothetical port 0 , and has to deliver them to hypothetical ports 1 and 2 respectively, and then proceed to port 3 in ballast. Interport distances are given by Table 2 .

Table 2: Interport distances (in nautical miles)

\begin{tabular}{|l|l|l|l|l|}
\hline$i j j$ & 0 & 1 & 2 & 3 \\
\hline 0 & - & 200 & 180 & 360 \\
\hline 1 & 200 & - & 160 & 180 \\
\hline 2 & 180 & 160 & - & 200 \\
\hline 3 & 360 & 180 & 200 & - \\
\hline
\end{tabular}

For simplicity assume port dwell times are zero. Note that the route of the ship in this example is an open path as the ship does not return to port 0 , but this causes no loss of generality as the path and tour problems are reducible to one another (or one could assume that the ship after visiting port 3 returns to port 0 ).

Assume that daily fuel consumption (in tonnes) is equal to $F C=k v^{3}(w+A)^{2 / 3}$, where $v$ is the ship speed, $w$ is the payload and $k$ is a constant such that at full capacity and at a speed of 14 knots fuel consumption is 30 tonnes/day. For simplicity also assume that the ship's maximum and minimum speeds are 14 and 8 knots respectively, and are independent of payload. Assume finally that $P_{\text {FUEL }}=\$ 600 /$ tonne and that $\alpha=\beta=0$ (ignore cargo inventory costs).

In case the ship wants to minimize total emissions (or equivalently minimize total fuel consumed or total fuel cost), it is straighforward to see that all legs should be sailed at the minimum speed ( 8 knots) and that the optimal route is 01-2-3 (Fig. 3). This is so even though total distance sailed (560 nautical miles) is longer than that of the alternative route $0-2-1-3$ (520 nautical miles). The reason that $0-1-2-3$ is better than $0-2-1-3$ is because in $0-1-2-3$ the heavier cargo is delivered first, which makes the ship consume less fuel in subsequent legs (and in total). Table 3 shows these calculations.

\footnotetext{
${ }^{7}$ In terms of ship size, this corresponds roughly to a feeder containership of about 1,000 TEU capacity. It could also be a product carrier or a small bulk carrier.
} 


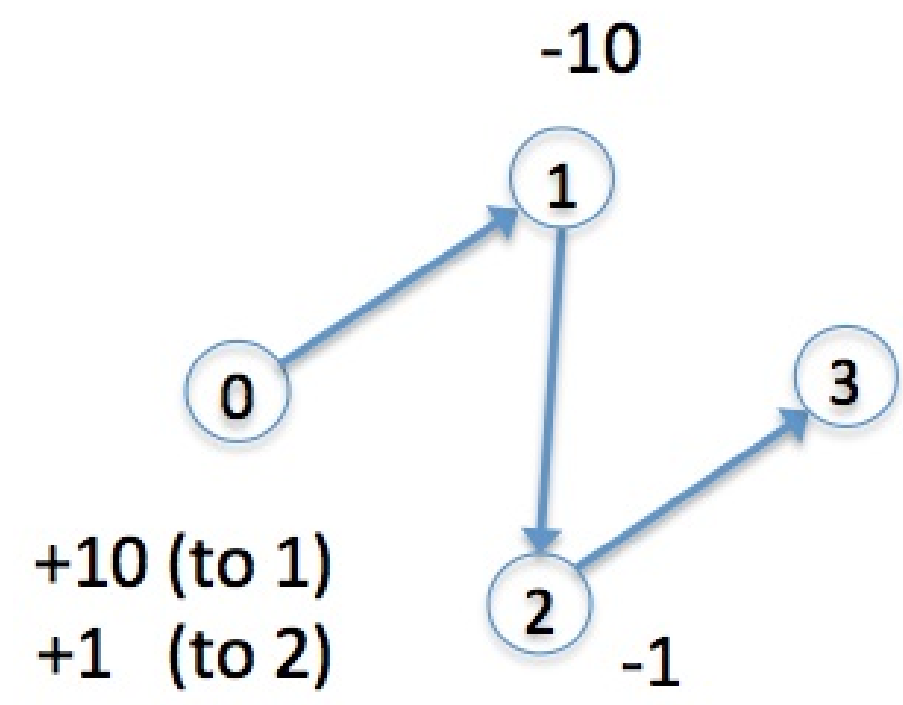

Figure 3: Optimal route to minimize total emissions

Table 3: Minimum emissions solution (optimal speed=8 knots)

\begin{tabular}{|c|c|c|c|}
\hline & $\begin{array}{l}\text { Fuel consumption } \\
\text { (tonnes) }\end{array}$ & $\begin{array}{l}\text { Fuel } \\
\text { cost }(\$)\end{array}$ & $\begin{array}{l}\text { Trip time } \\
\text { (days) }\end{array}$ \\
\hline \multicolumn{4}{|l|}{ Route $0-1-2-3$} \\
\hline Leg 0-1 (200 nm) & 5.83 & 3,499 & 1.04 \\
\hline Leg 1-2 (160 nm) & 2.43 & 1,455 & 0.83 \\
\hline Leg 2-3 (200 nm) & 2.69 & 1,611 & 1.04 \\
\hline Total $(560 \mathrm{~nm})$ & 10.94 & 6,565 & 2.92 \\
\hline Total $\mathrm{CO}_{2}$ emissions (tonnes) & 34.02 & & \\
\hline \multicolumn{4}{|l|}{ Route 0-2-1-3 } \\
\hline Leg 0-2 (180 nm) & 5.25 & 3,149 & 0.94 \\
\hline Leg 2-1 (160 nm) & 4.47 & 2,681 & 0.83 \\
\hline Leg 1-3 (180 nm) & 2.42 & 1,450 & 0.94 \\
\hline Total $(520 \mathrm{~nm})$ & 12.13 & 7,280 & 2.71 \\
\hline Total $\mathrm{CO}_{2}$ emissions (tonnes) & 37.72 & & \\
\hline
\end{tabular}

However, if the objective is to minimize total cost, including cost paid for chartering the ship at a rate of $F(\$ /$ day), then if $F$ is high enough the ship would follow the shorter route $0-2-1-3$, even though in this case the heavier cargo would be delivered last (Fig. 4). Table 4 summarizes the cost components for both routes if $F=\$ 15,000 /$ day. 


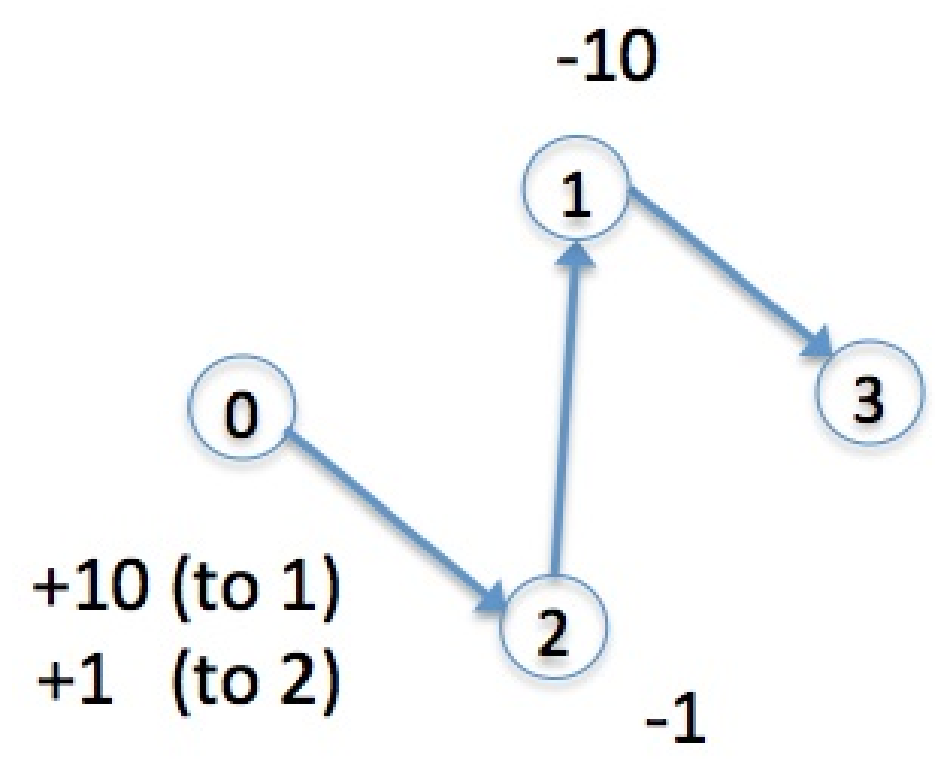

Figure 4: Optimal route to minimize total cost

Table 4: Minimum total cost solution

\begin{tabular}{|c|c|c|c|c|c|c|}
\hline & $\begin{array}{l}\text { Optimal } \\
\text { speed } \\
\text { (knots) }\end{array}$ & $\begin{array}{l}\text { Fuel } \\
\text { consumption } \\
\text { (tonnes) }\end{array}$ & $\begin{array}{l}\text { Fuel cost } \\
(\$)\end{array}$ & $\begin{array}{l}\text { Chartering } \\
\text { cost }(\$)\end{array}$ & $\begin{array}{l}\text { Total } \\
\text { cost }(\$)\end{array}$ & $\begin{array}{l}\text { Trip } \\
\text { time } \\
\text { (days) }\end{array}$ \\
\hline \multicolumn{7}{|l|}{ Route $0-1-2-3$} \\
\hline Leg 0-1 (200 nm) & 10.46 & 9.96 & 5,977 & 11,954 & 17,931 & 0.80 \\
\hline Leg 1-2 (160 nm) & 13.00 & 6.41 & 3,845 & 7,690 & 11,536 & 0.51 \\
\hline Leg 2-3 (200 nm) & 13.54 & 7.69 & 4,616 & 9,231 & 13,847 & 0.62 \\
\hline Total $(560 \mathrm{~nm})$ & & 24.06 & 14,438 & 28,876 & 43,314 & 1.93 \\
\hline $\begin{array}{l}\text { Total } \mathrm{CO}_{2} \\
\text { emissions } \\
\text { (tonnes) }\end{array}$ & & 74.83 & & & & \\
\hline \multicolumn{7}{|l|}{ Route 0-2-1-3 } \\
\hline Leg 0-2 (180 nm) & 10.46 & 8.97 & 5.379 & 10.759 & 16.138 & 0.72 \\
\hline Leg 2-1 (160 nm) & 10.61 & 7.86 & 4,714 & 9,427 & 14,141 & 0.63 \\
\hline Leg 1-3 (180 nm) & 13.54 & 6.92 & 4,154 & 8,308 & 12,462 & 0.55 \\
\hline Total $(520 \mathrm{~nm})$ & & 23.75 & 14,247 & 28,494 & 42,741 & 1.90 \\
\hline $\begin{array}{l}\text { Total } \mathrm{CO}_{2} \\
\text { emissions } \\
\text { (tonnes) }\end{array}$ & & 73.86 & & & & \\
\hline
\end{tabular}

Table 4 also shows the optimal ship speed in all legs of the route.

\subsection{Multiple optimal speeds versus a single optimal speed}

A corollary of the above is that if ship payload varies along the ship's route, optimizing ship speed at each leg of the route is better than finding a single optimal speed, the same for all legs. This is of course to be expected, as the 
feasible solution space of the single speed case is a subset of the feasible solution space of the multiple speed case.

As an example, consider a fixed-route scenario with the ship of the previous example assumed to be a small containership engaged in a transMediterranean trade, and visiting, in this order, the ports of Algeciras, Valencia and Barcelona (Spain), then Marseille (France), and finally Genoa and Gioia Tauro (Italy). See Fig. 5.

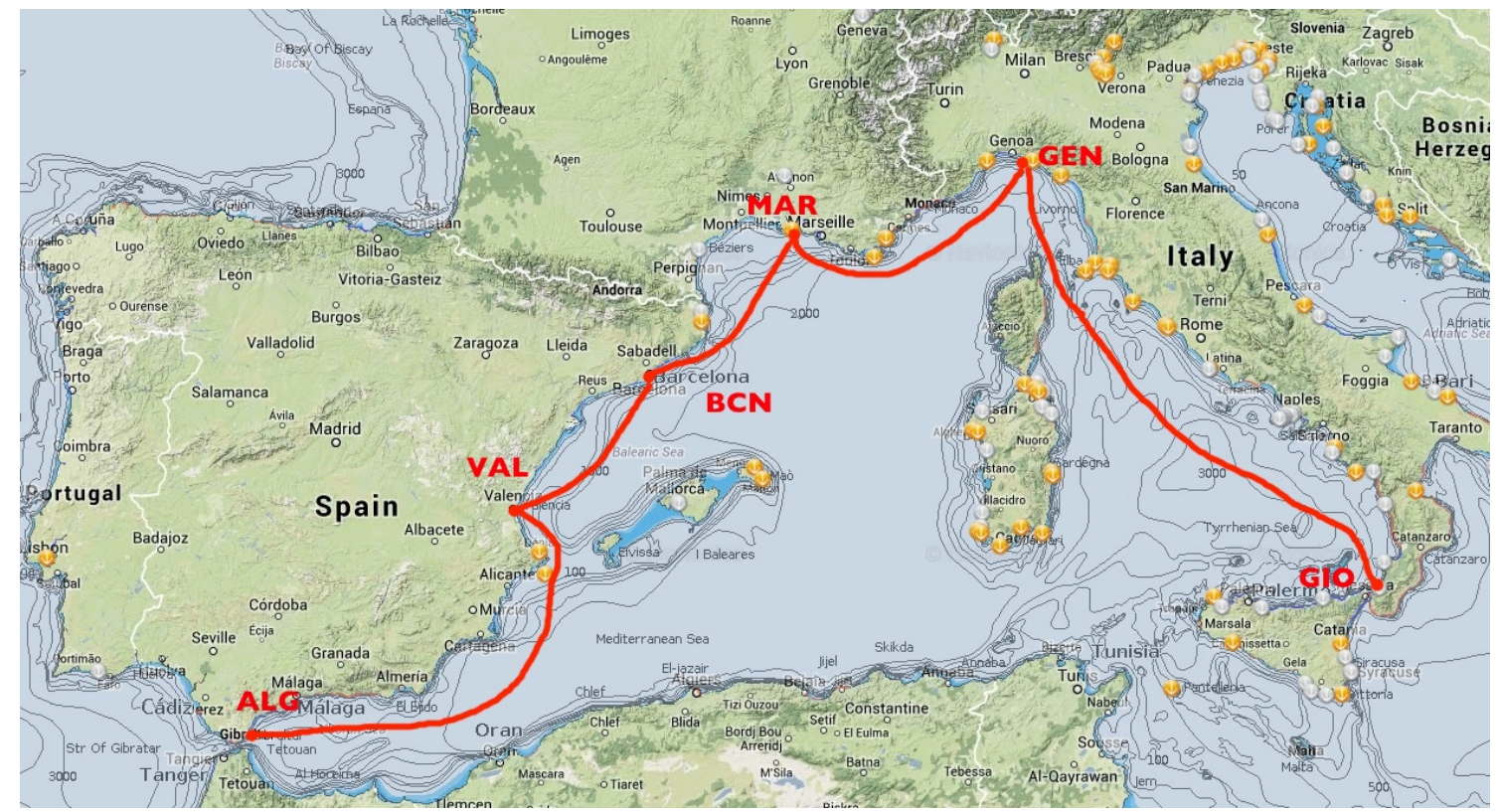

Figure 5: A trans-Mediterranean route

Assume the ship starts empty at Algeciras and has to collect cargo shipments of sizes 5,1,2 and 3 (in thousand tonnes) at Valencia, Marseille and Genoa respectively, and deliver all of them to Gioia Tauro. As before, assume that $P_{\text {FUEL }}$ is $\$ 600 /$ tonne, that $\mathrm{F}$ is $\$ 15,000 /$ day and that port dwell times can be ignored.

Note that in this scenario, if the fuel consumption function is assumed independent of ship payload, the ship's computed optimal speed will be the same on each leg of the route. However, with a payload-dependent fuel consumption function, different speeds on each leg would generally be warranted.

Table 5 shows the results of the variable speed scenario.

Table 5: Results of the variable speed per leg scenario

\begin{tabular}{|l|l|l|l|l|l|l|c|}
\hline Leg & $\begin{array}{l}\text { Distance } \\
(\mathrm{nm})\end{array}$ & $\begin{array}{l}\text { Payload } \\
(000 \\
\text { tonnes })\end{array}$ & $\begin{array}{l}\text { Speed } \\
(\mathrm{knots})\end{array}$ & $\begin{array}{l}\text { Fuel } \\
\text { cost }(\$)\end{array}$ & $\begin{array}{l}\text { Charter } \\
\text { cost }(\$)\end{array}$ & $\begin{array}{l}\text { Total } \\
\text { cost (\$) }\end{array}$ & $\begin{array}{l}\text { Trip time } \\
\text { (days) }\end{array}$ \\
\hline ALG-VAL & 396 & 0 & 13.54 & 9,139 & 18,278 & 27,417 & 1.22 \\
\hline VAL-BCN & 165 & 5 & 11.61 & 4,442 & 8,884 & 13,326 & 0.59 \\
\hline
\end{tabular}




\begin{tabular}{|l|c|c|c|c|c|c|c|}
\hline BCN-MAR & 191 & 6 & 11.36 & 5,252 & 10,504 & 15,756 & 0.70 \\
\hline MAR-GEN & 201 & 8 & 10.95 & 5,736 & 11,472 & 17,208 & 0.76 \\
\hline GEN-GIO & 508 & 11 & 10.46 & 15,182 & 30,364 & 45,545 & 2.02 \\
\hline TOTAL & 1,461 & & & 39,751 & 79,502 & 119,253 & 5.30 \\
\hline
\end{tabular}

A pertinent question is, with the same fuel consumption function, if for whatever reason the ship is to keep the same speed along the route, can we at least find the common speed that minimizes total cost? It turns out that this speed is 11.375 knots, as shown in Fig. 6 below.

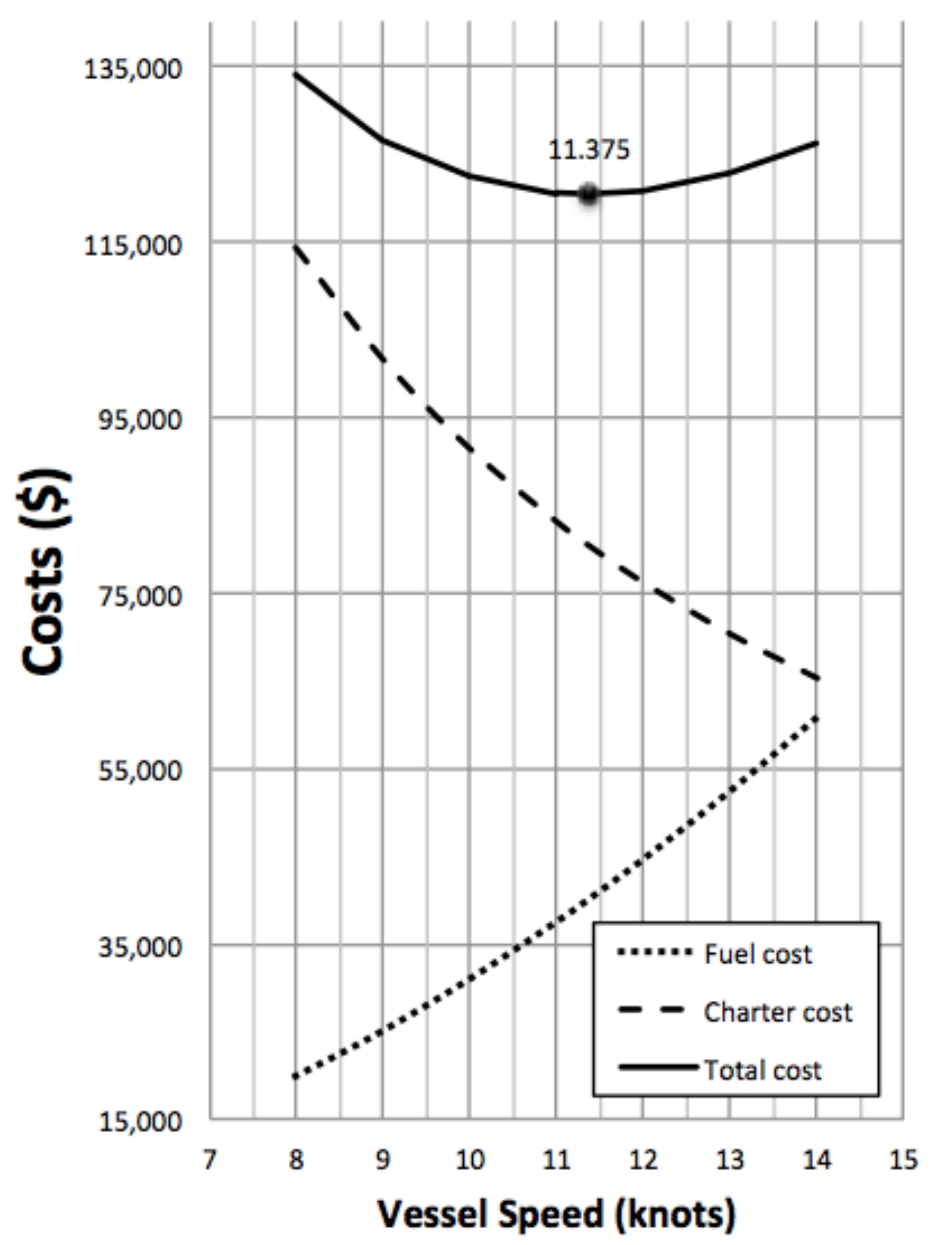

Figure 6: Fuel, Charter and Total costs as functions of vessel speed

Table 6 shows detailed results of this scenario.

Table 6: Results of the fixed speed scenario

\begin{tabular}{|c|c|c|c|c|c|c|c|}
\hline Leg & $\begin{array}{c}\text { Distance } \\
(\mathrm{nm})\end{array}$ & $\begin{array}{l}\text { Payload } \\
(000 \\
\text { tonnes })\end{array}$ & $\begin{array}{c}\text { Speed } \\
(\mathrm{knots})\end{array}$ & $\begin{array}{c}\text { Fuel } \\
\text { cost }(\$)\end{array}$ & $\begin{array}{c}\text { Charter } \\
\text { cost }(\$)\end{array}$ & $\begin{array}{c}\text { Total } \\
\text { cost }(\$)\end{array}$ & $\begin{array}{c}\text { Trip time } \\
\text { (days) }\end{array}$ \\
\hline ALG-VAL & 396 & 0 & 11.375 & 6,449 & 21,758 & 28,207 & 1.45 \\
\hline
\end{tabular}




\begin{tabular}{|c|c|c|c|c|c|c|c|}
\hline VAL-BCN & 165 & 5 & 11.375 & 4,266 & 9,066 & 13,332 & 0.60 \\
\hline BCN-MAR & 191 & 6 & 11.375 & 5,262 & 10,495 & 15,756 & 0.70 \\
\hline MAR-GEN & 201 & 8 & 11.375 & 6,190 & 11,044 & 17,233 & 0.74 \\
\hline GEN-GIO & 508 & 11 & 11.375 & 17,966 & 27,912 & 45,878 & 1.86 \\
\hline TOTAL & 1,461 & & & 40,132 & 80,275 & 120,407 & 5.35 \\
\hline
\end{tabular}

In comparing Tables 5 and 6 , one can compare the results of the two scenarios. As expected, the results of Table 5 are better for the objective to be optimized (total cost in this case). But it happens that in this instance better results are also obtained with respect to total fuel cost, total charter cost and total trip time. Note also that the single optimal speed (11.375 knots) is lower than the average speed of the multiple optimal speed scenario (11.48 knots). The difference in total costs depends on the scenario. For this one, they are not that pronounced.

If the charter rate $F$ is higher, optimal speeds will tend to increase, and this is true for both the single optimal speed and for the multiple optimal speed scenarios. Figure 7 shows such a behavior, by plotting the optimal (single) speed as a function of the charter rate.

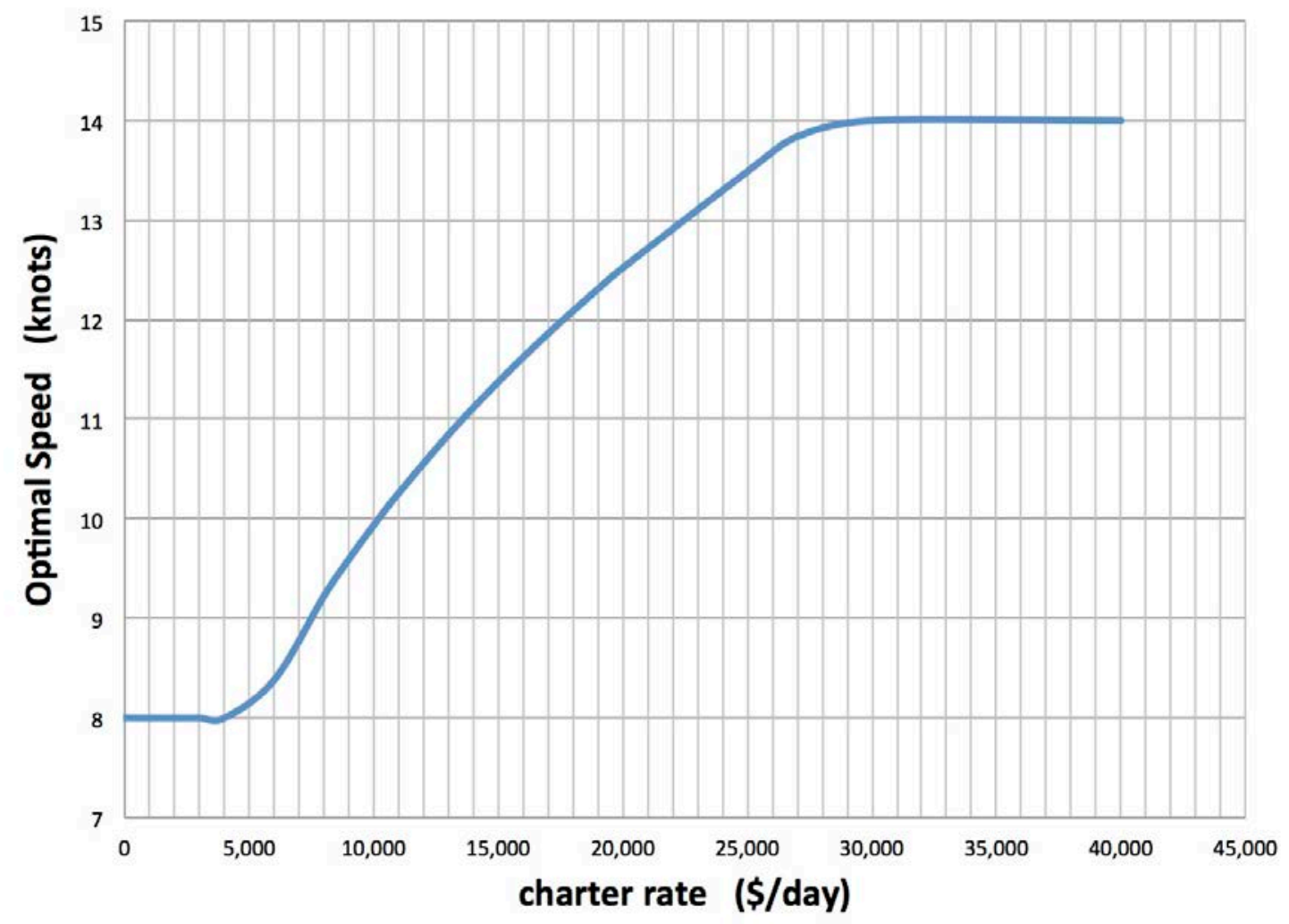

Figure 7: Optimal speed as a function of the charter rate

Fig. 7 captures a typical market behavior in shipping: ships tend to speed up when the market is up, and slow down when the market is down. Also it can be seen that above or below certain charter rates, the speed hits its upper or lower bounds respectively. 
A similar behavior also pertains to variations in fuel price. For this particular form of fuel consumption function, keeping the ratio of fuel price to charter rate constant would result in the same speeds.

The above results also tend to confirm those of Gkonis and Psaraftis (2012), to the effect that, in the absence of constraints on laden speed, if one wishes to reduce fuel costs and by extension emissions, it is better to apply speed reduction in the laden condition than in the ballast condition. Extending this argument, the more loaded the ship is, the lower its speed should be. In practice however, the opposite is often the case, as many ships maintain a constant speed and tend to sail faster when laden than in ballast. This behavior can be explained if there are contractual obligations or other constraints that force the ship to sail at the laden condition faster than in the ballast condition, or if cargo inventory costs are taken into account. This point is further elaborated next.

\subsection{Expensive cargoes sail faster and induce more $\mathrm{CO}_{2}$}

If we take cargo inventory costs into account in the previous example, optimal per leg speeds will change. The more expensive the cargo, the higher the optimal speed will be. If we assume that $\alpha=0$ (just-in-time availability of cargoes at loading ports) and $\beta=P R / 365$ with $P$ the CIF value of the cargo and $R$ the cargo owner's cost of capital, Table 7 exhibits the optimal speeds per leg for various values of the cargo, assuming $R=3 \%$. The zero value case corresponds to the case that cargo inventory costs are not factored in. The table also shows all cost components, total tonnes of $\mathrm{CO}_{2}$ emitted and trip time in each case.

Table 7: Variation of optimal speed with value of cargo

\begin{tabular}{|c|c|c|c|c|c|c|c|c|}
\hline \multicolumn{2}{|c|}{$\begin{array}{l}\text { VALUE OF } \\
\text { CARGO (\$/tonne) }\end{array}$} & & 0 & 5,000 & 10,000 & 15,000 & 20,000 & 25,000 \\
\hline \multirow{6}{*}{ త্త } & & $\begin{array}{l}\text { Payload } \\
(000 \\
\text { tonnes) }\end{array}$ & \multicolumn{6}{|c|}{ Speed (knots) } \\
\hline & ALG-VAL & 0 & 13.54 & 13.54 & 13.54 & 13.54 & 13.54 & 13.54 \\
\hline & VAL-BCN & 5 & 11.61 & 12.12 & 12.58 & 13.02 & 13.43 & 13.81 \\
\hline & BCN-MAR & 6 & 11.36 & 11.96 & 12.49 & 12.99 & 13.45 & 13.88 \\
\hline & MAR-GEN & 8 & 10.95 & 11.70 & 12.36 & 12.96 & 13.51 & 14.00 \\
\hline & GEN-GIO & 11 & 10.46 & 11.42 & 12.24 & 12.96 & 13.61 & 14.00 \\
\hline \multicolumn{3}{|c|}{ FUEL COST (\$) } & 1 & & & & & \\
\hline \multirow{2}{*}{\multicolumn{3}{|c|}{ CHARTER COST (\$) }} & $39,13 \perp$ & 44,430 & 40,000 & 02,945 & 50,090 & 59,054 \\
\hline & & & 79,502 & 75,324 & 72,136 & 69,580 & 67,461 & 65,996 \\
\hline \multicolumn{3}{|c|}{ INVENTORY COST(\$) } & 0 & 13,542 & 25,480 & 36,310 & 46,318 & 56,189 \\
\hline \multicolumn{3}{|c|}{ TOTAL COST (\$) } & 119,253 & 133,299 & 146,424 & 158,835 & 170,669 & 182,039 \\
\hline \multicolumn{3}{|c|}{$\mathrm{CO}_{2}$ EMITTED (tonnes) } & 206.04 & 230.31 & 252.99 & 274.43 & 294.88 & 310.24 \\
\hline \multicolumn{3}{|c|}{ TRIP TIME (days) } & 5,30 & 5,02 & 4,81 & 4,64 & 4,50 & 4,40 \\
\hline
\end{tabular}


One can observe that, with the exception of the first leg, which is in ballast, all other legs are sailed at a higher speed for more expensive cargoes. In fact, even though there is an initial downward trend in speed along the route as the ship becomes more heavy with cargoes loaded on to it, above a certain value of cargo (about $\$ 15,000 /$ tonne here) this trend is reversed and speed increases with payload, hitting its upper bound of 14 knots in the last two legs of the trip if the value of the cargo is $\$ 25,000 /$ tonne. Further increases in the value of the cargo would set all leg speeds (except that of the first leg) to this upper bound.

One can also observe that expensive cargoes induce more $\mathrm{CO}_{2}$, as they encourage higher speeds for the ship.

\subsection{Sailing the minimum distance route at minimum speed may not minimize emissions}

In the quest for environmentally optimal solutions, one might assume that if the minimum distance route is sailed at the minimum possible speed in all legs, this would minimize emissions. After all, daily emissions are an increasing function of ship speed, and more days at sea would seem to imply more emissions. However, it turns out that this is not necessarily the case, as shown in the rudimentary example below, involving a pickup and delivery scenario.

Assume a 4-port problem (the home port 0 plus 3 other ports) with the distance matrix given by Table 8 as follows:

Table 8: Interport distances (in nautical miles)

\begin{tabular}{|l|l|l|l|l|}
\hline$i j j$ & 0 & 1 & 2 & 3 \\
\hline 0 & - & 255 & 175 & 10 \\
\hline 1 & 255 & - & 200 & 250 \\
\hline 2 & 175 & 200 & - & 170 \\
\hline 3 & 10 & 250 & 170 & - \\
\hline
\end{tabular}

Also assume an asymmetric O/D table for six (6) cargoes to be transported among ports 1 to 3 as given by Table 9:

Table 9: Cargo O/D matrix [d] (in thousand tonnes)

\begin{tabular}{|l|l|l|l|}
\hline$i j j$ & 1 & 2 & 3 \\
\hline 1 & - & 5 & 3 \\
\hline 2 & 2 & - & 4 \\
\hline 3 & 11 & 1 & - \\
\hline
\end{tabular}

We again assume the same feeder ship of the previous examples. The ship starts and ends at port 0 , and has to visit the three ports as many times as necessary in order to carry all cargoes as shown in the O/D table. Note that one of the cargoes (from port 3 to port 1 ) is of size equal to the capacity of the ship. In this example we ignore cargo inventory costs, meaning that $\alpha=\beta=0$.

If the objective is minimum trip time (this is achieved if we set $P_{\text {FUEL }}=0$ ), all legs are sailed (as expected) at the maximum speed of 14 knots, and the ship 
makes a total of 6 port calls (once at port 2, twice at port 1 and three times at port 3) as follows (Table 10):

Table 10: Minimum trip time solution

\begin{tabular}{|l|l|l|r|r|r|r|}
\hline $\begin{array}{l}\text { Port } \\
\text { stop }\end{array}$ & $\begin{array}{l}\text { Pickup and } \\
\text { delivery } \\
\text { operations }\end{array}$ & $\begin{array}{l}\text { Lext } \\
\text { Leg }\end{array}$ & $\begin{array}{l}\text { Payload at } \\
\text { beginning of } \\
\text { leg } \\
\text { tonnes) }\end{array}$ & $\begin{array}{l}\text { Speed } \\
\text { (knots) }\end{array}$ & $\begin{array}{l}\text { Distance } \\
\text { (nm) }\end{array}$ & $\begin{array}{l}\text { Trip time } \\
\text { (days) }\end{array}$ \\
\hline 0 & - & 0 & 14.00 & 10 & 0.03 \\
\hline 3 & P31 & $3-1$ & 14 & 14.00 & 250 & 0.74 \\
\hline 1 & $\begin{array}{l}\text { D31,P12, } \\
\text { P13 }\end{array}$ & $1-3$ & 8 & 14.00 & 250 & 0.74 \\
\hline 3 & D13, P32 & $3-2$ & 6 & 14.00 & 170 & 0.51 \\
\hline 2 & $\begin{array}{l}\text { D12,D32, } \\
\text { P21, P23 }\end{array}$ & $2-1$ & 6 & 14.00 & 200 & 0.60 \\
\hline 1 & D21 & $1-3$ & 4 & 14.00 & 250 & 0.74 \\
\hline 3 & D23 & $3-0$ & 0 & 14.00 & 10 & 0.03 \\
\hline 0 & - & - & - & - & - & 3.39 \\
\hline
\end{tabular}

In Tables 10 to 12, by "Pxy" we mean "at port x pick up cargo destined to port $y$," and by "Dxy" we mean "at port y deliver cargo originating from port $x . "$

In this case total distance traveled is also minimized and equal to 1,140 nautical miles, and total $\mathrm{CO}_{2}$ emitted is 260 tonnes. Total trip time is equal to 3.39 days. This solution is independent of $F$, so long as $F$ is not zero.

At the other extreme of this example is if we examine the minimum emissions (or minimum fuel consumption) solution. We can do this by setting $F=0$ and assuming any nonzero fuel price.

If this is the case, the ship will make 7 port calls instead of 6 (twice at ports 1 and 2 and three times at port 3), and will sail all legs at the minimum speed of 8 knots. The solution will be as follows (Table 11):

Table 11: Minimum emissions solution

\begin{tabular}{|l|l|l|l|r|r|r|}
\hline $\begin{array}{l}\text { Port } \\
\text { stop }\end{array}$ & $\begin{array}{l}\text { Pickup } \\
\text { delivery } \\
\text { operations }\end{array}$ & $\begin{array}{l}\text { Next } \\
\text { Leg }\end{array}$ & $\begin{array}{l}\text { Payload at } \\
\text { beginning of } \\
\text { leg } \\
\text { (000 tonnes) }\end{array}$ & $\begin{array}{l}\text { Speed } \\
(\text { knots })\end{array}$ & $\begin{array}{l}\text { Distance } \\
(\mathrm{nm})\end{array}$ & $\begin{array}{l}\text { Trip time } \\
\text { (days) }\end{array}$ \\
\hline 0 & - & 0 & 8.00 & 10 & 0.05 \\
\hline 3 & P31 & $3-1$ & 11 & 8.00 & 250 & 1.30 \\
\hline 1 & D31, P12 & $1-2$ & 5 & 8.00 & 200 & 1.04 \\
\hline 2 & D12, P21 & $2-1$ & 2 & 8.00 & 200 & 1.04 \\
\hline 1 & D21, P13 & $1-3$ & 3 & 8.00 & 250 & 1.30 \\
\hline 3 & D13, P32 & $3-2$ & 1 & 8.00 & 170 & 0.89 \\
\hline 2 & D32, P23 & $2-3$ & 4 & 8.00 & 170 & 0.89 \\
\hline 3 & D23 & $3-0$ & 0 & 8.00 & 10 & 0.05 \\
\hline
\end{tabular}




\begin{tabular}{|l|l|l|l|r|r|r|}
\hline 0 & - & - & - & - & - & \\
\hline & & & TOTAL & 1,260 & 6.56 \\
\hline
\end{tabular}

Total distance traveled in this case will be 1,260 nautical miles and total trip time will be 6.56 days, both higher than before. But total $\mathrm{CO}_{2}$ emitted will only be 80 tonnes, much lower. Obviously the lower emissions are mainly due to the lower speed. However, it is interesting to note that the amount of $\mathrm{CO}_{2}$ emitted in this case is lower than the 84.90 tonnes of $\mathrm{CO}_{2}$ that would be emitted if the ship had sailed the minimum distance route of Table 10 at the minimum speed of 8 $k{ }^{2}{ }^{8}$. The reason that sailing the minimum distance route at minimum speed is suboptimal with respect to emissions is that it involves more legs in which the ship is more laden as compared to the case it sails the alternate, longer route. A heavier load profile results in higher fuel consumption (and emissions) overall, even though the route is shorter. So in this case what would intuitively seem like an optimal policy is actually suboptimal.

Other solutions may be produced for different values of the input data. Table 12 shows two cases where $P_{\text {FUEL }}=\$ 600 /$ tonne (in both cases) and $F$ is either $\$ 5,000 /$ day or $\$ 20,000$ day. Both cases produce the same optimal route as that of Table 10, but speeds along the legs of the route will vary for different values of $F$.

Table 12: Solutions for non-zero fuel price and varying freight rates

\begin{tabular}{|c|c|c|c|c|c|c|c|}
\hline \multirow{2}{*}{$\begin{array}{l}\text { Port } \\
\text { stop }\end{array}$} & \multirow{2}{*}{$\begin{array}{l}\text { Pickup \& } \\
\text { delivery } \\
\text { operations }\end{array}$} & \multirow{2}{*}{$\begin{array}{l}\text { Next } \\
\text { Leg }\end{array}$} & \multirow{2}{*}{$\begin{array}{l}\text { Payload } \\
\text { at } \\
\text { beginning } \\
\text { of leg } \\
\text { (000 } \\
\text { tonnes) }\end{array}$} & \multicolumn{2}{|c|}{ Speed (knots) } & \multicolumn{2}{|c|}{ Trip time (days) } \\
\hline & & & & $\begin{array}{l}\$ 5,000 \\
\text { per day }\end{array}$ & $\begin{array}{l}\$ 20,000 \\
\text { per day }\end{array}$ & $\begin{array}{l}\$ 5,000 \\
\text { per } \\
\text { day }\end{array}$ & $\begin{array}{l}\$ 20,000 \\
\text { per day }\end{array}$ \\
\hline 0 & - & $0-3$ & 0 & 9.39 & 14.00 & 0.04 & 0.03 \\
\hline 3 & P31 & $3-1$ & 11 & 8.00 & 11.51 & 1.30 & 0.91 \\
\hline 1 & $\begin{array}{l}\text { D31, P12, } \\
\text { P13 }\end{array}$ & $1-3$ & 8 & 8.00 & 12.05 & 1.30 & 0.86 \\
\hline 3 & D13, P32 & $3-2$ & 6 & 8.00 & 12.51 & 0.89 & 0.57 \\
\hline 2 & $\begin{array}{l}\mathrm{D} 12, \mathrm{D} 32, \\
\mathrm{P} 21, \mathrm{P} 23\end{array}$ & $2-1$ & 6 & 8.00 & 12.51 & 1.04 & 0.67 \\
\hline 1 & D21 & $1-3$ & 4 & 8.24 & 13.08 & 1.26 & 0.80 \\
\hline 3 & D23 & $3-0$ & 0 & 9.39 & 14.00 & 0.04 & 0.03 \\
\hline 0 & - & - & - & - & - & - & \\
\hline & & & & & TOTAL & 5.87 & 3.87 \\
\hline
\end{tabular}

As expected, the ship goes faster when $F$ is higher, with the lower speed bound active in 4 legs of the $F=\$ 5,000 /$ day case and the upper speed bound active in 2 legs of the $F=\$ 20,000 /$ day case.

\footnotetext{
${ }^{8}$ For a cubic fuel consumption function, total fuel consumed (and hence $\mathrm{CO}_{2}$ produced) is proportional to the square of the speed, everything else (including payloads at each leg) being equal. $260(8 / 14)^{2}=84.90$.
} 
We mention that the above examples were solved by dynamic programming, in a straightforward extension of the algorithm of Psaraftis (2011), so as to embed speed optimization. The related algorithm is described in the Appendix to this paper.

\section{Conclusions}

This paper has clarified some important issues as regards ship speed optimization and developed models that optimize ship speed for a spectrum of routing scenarios and for several variants that concern the objective function to be optimized. In our opinion, the main contribution of this paper vis-a-vis the state of the art is the incorporation of those fundamental parameters and other considerations that weigh the most in a ship owner's or charterer's speed decision at the operational level (and as it turns out, also the routing decision, wherever relevant). These are (a) the fuel price, (b) the state of the market (freight rate), (c) the inventory cost of the cargo, and (d) the dependency of fuel consumption on payload. To that effect, it can hopefully contribute to further research in this area, for instance in multiple ship problems where many of the properties identified in this paper are still valid.

The paper has confirmed that solutions for optimal environmental performance are not necessarily the same as those for optimal economic performance. Also policies that may seem at first glance optimal from an environmental viewpoint may actually be suboptimal. As a private operator would most certainly choose optimal economic performance as a criterion, if policy-makers want to influence the operator in his decision so as to achieve results that are good from a societal point of view, they could play with parameters that would internalize the external costs of $\mathrm{CO}_{2}$ produced and move the solution closer to what is deemed more appropriate for the environment and for the benefit of society. For instance, imposing a tax on fuel would artificially increase fuel prices, induce slower steaming and further reduce emissions.

In the quest for a balanced economic and environmental performance of maritime transport, we think that this work can provide useful insights.

\section{Acknowledgments}

Work on this paper has been supported in part by The Lloyd's Register Foundation (LRF) in the context of the Centre of Excellence in Ship Total Energy-Emissions-Economy at the National Technical University of Athens (NTUA), the authors' former affiliation, and by an internal grant at the Technical University of Denmark (DTU). LRF helps to protect life and property by supporting engineering-related education, public engagement and the application of research.

\section{References}

Agarwal, R. and Ergun, Ö. (2008). Ship Scheduling and Network Design for Cargo routing in Liner Shipping. Transportation Science 42(2), 175-196. 
Barrass, C.B. (2005). Ship Design and Performance for Masters and Mates. Butterworth-Heinemann, UK.

Bektas, T. and Laporte, G. (2011). The Pollution-Routing Problem. Transportation Research Part B 45 1232-1250.

CBO (2006). The Economic Costs of Disruptions in Container Shipments, U.S. Congress, Congressional Budget Office, Washington, DC.

Cariou, P., and Cheaitou, A., 2012. The effectiveness of a European speed limit versus an international bunker-levy to reduce $\mathrm{CO}_{2}$ emissions from container shipping. Transportation Research Part D, 17, 116-123.

Cordeau, J.-F., Laporte, G. , Legato P. and Moccia, L. (2005). Models and Tabu Search Heuristics for the Berth-Allocation Problem. Transportation Science 39(4), 526-538.

Devanney, J.W.,(2007). Solving Elastic Transportation Networks. Center for Tankship Excellence [online], Available at: www.c4tx.org.

Devanney, J.W. (2010). The Impact of Bunker Price on VLCC Spot Rates. Proc. Of the 3rd International Symposium on Ship Operations, Management and Economics, SNAME Greek Section, Athens, Greece, October.

Erdoğan,S. and Miller-Hooks, E. (2011). Green Vehicle Routing Problem. Transportation Research Part E: Logistics and Transportation Review, doi:10.1016/j.tre.2011.08.001

Fagerholt, K. and D. Ronen (2013), Bulk ship routing and scheduling: solving practical problems may provide better results, Maritime Policy and Management, 40 (1), 48-64.

Figliozzi, M. (2010). Vehicle Routing Problem for Emissions Minimization", Transportation Research Record: Journal of the Transportation Research Board, No. 2197, Transportation Research Board of the National Academies, Washington, D.C., 2010, pp. 1-7.

Gkonis, K.G. and Psaraftis, H.N. (2012). Modelling tankers' optimal speed and emissions. SNAME 2012 Transactions, Vol. 120, 90-115.

Grønhaug, R., Christiansen, M., Desaulniers,G. and Desrosiers, J. (2010). A Branch-and-Price Method for a Liquefied Natural Gas Inventory Routing Problem. Transportation Science 44(3), 400-415.

Hvattum, L. M., Norstad, I, Fagerholt, K., and Laporte, G., (2013). Analysis of an exact algorithm for the vessel speed optimization problem. Networks, Vol. 62 , No. 2, 132-135.

Hwang, H.-S., S. Visoldilokpun, and J.M. Rosenberger (2008). A Branch-and- 
Price-and-Cut Method for Ship Scheduling with Limited Risk. Transportation Science, Vol. 42, No. 3, 336-351.

IMO (2009). Second IMO GHG study 2009. doc. MEPC59/INF.10, International Maritime Organization (IMO), London, UK.

Kontovas, C.A. and Psaraftis, H.N. (2011). Reduction of Emissions Along the Maritime Intermodal Container Chain. Maritime Policy \& Management 38 (4), 455-473.

Kopfer H.W and Kopfer H. (2013). Emissions Minimization Vehicle Routing Problem in Dependence of Different Vehicle Classes. In H.-J. Kreowski et al. (eds.), Dynamics in Logistics, Lecture Notes in Logistics,Springer-Verlag Berlin Heidelberg.

Maersk (2013), Building the World's Biggest Ship.

http://www.maersk.com/innovation/leadingthroughinnovation/pages/buildingthe worldsbiggestship.aspx

Notteboom, T.E. and Vernimmen, B., (2010). The effect of high fuel costs on liner service configuration in container shipping. Journal of Transport Geography 17: 325-337.

Norstad, I., Fagerholt, K., Laporte, G., (2011). Tramp ship routing and scheduling with speed optimization. Transportation Research Part C 19, 853865.

Özceylan, E., Kiran, M.S., Atasagun, Y. (2011). A New Hybrid Heuristic Approach for Solving Green Traveling Salesman Problem. Proc. of 41st International Conference on Computers \& Industrial Engineering, October 2326, pp. 720-725, Los Angeles, USA.

Perakis, A.N., Jaramillo, D.I. (1991). Fleet deployment optimization for liner shipping. Part 1: Background, problem formulation and solution approaches. Maritime Policy and Management 18 (3), 183-200.

Psaraftis, H.N. (2011). A multi-commodity, capacitated pickup and delivery problem: The single and two-vehicle cases. European Journal of Operational Research 215, 572-580.

Psaraftis, H.N., Kontovas, C.A. (2009). $\mathrm{CO}_{2}$ Emissions Statistics for the World Commercial Fleet. WMU Journal of Maritime Affairs,Vol. 8 :1, 1-25.

Psaraftis, H.N., Kontovas, C.A. (2013). Speed Models for Energy-Efficient Maritime Transportation: a Taxomomy and Survey. Transportation Research Part C, 26, 331-351.

Rana, K., and R.G. Vickson (1991). Routing Container Ships Using Lagrangean Relaxation and Decomposition. Transportation Science, 25(3) , 201-214. 
Ronen, D., 1982. The effect of oil price on the optimal speed of ships. Journal of the Operational Research Society 33, 1035-1040.

Song, D.P., Xu, J.J., (2012). CO2 emission comparison between direct and feeder liner services: a case study of Asia-Europe services interfacing with the UK. International Journal of Sustainable Transportation 6 (4), 214-237.

TradeWinds (2009). Maersk insists on slow speeds. TradeWinds magazine, 30 October. 


\section{APPENDIX}

\section{A dynamic programming algorithm for pickup and delivery scenarios}

For pickup and delivery scenarios, the decomposition property of the optimal solution identified in section 4.1 is valid whatever the scenario and whetever algorithm is used to produce the ship's route, either exact or heuristic. Even if a heuristic algorithm is used, it would not make sense for the ship that sails a specific leg of the route to have an operating speed that is different from the optimal speed for that leg, as computed in section 4.1. A fortiori, the same is true if an exact algorithm is used.

An exact algorithm that can easily embed the above property, along with all other input parameters, and is flexible enough to allow for the spectrum of variants as regards the possible objective functions is one that is based on dynamic programming, and is a straightforward extension of the approach developed in Psaraftis (2011). That paper had assumed a general pick up and delivery setting with known and fixed arc traversal costs and times, zero dwell times and vehicle speed was not a decision variable. Further, there was no effect of $F$ to be taken into account.

The approach goes as follows.

Define the matrix $\left[k_{i j}\right]$ and optimal value function $V$ as follows:

$$
k_{i j}=\left\{\begin{array}{l}
3 \text { if cargo from } i \text { to } j \text { has not been picked up yet } \\
2 \text { if cargo from } i \text { to } j \text { is onboardtheship } \\
1 \text { if cargo fromito } j \text { hasbeendelivered }
\end{array}\right.
$$

$V\left(L,\left[k_{i j}\right]\right)=$ Minimum possible total cost to complete the trip from port $L$ to port 0 , by executing all pending actions on pickup and delivery of the cargoes, choosing optimal speeds and observing capacity constraints, given that the current status of the cargoes is described by matrix $\left[k_{i j}\right]$.

Define $M=$ large number. ${ }^{9}$

For a specific state $\left(L,\left[k_{i j}\right]\right)$, define set $R=\left\{(i, j): i \neq j, k_{i j} \neq 1\right\}$

If $R=\varnothing$, then

$$
V\left(L,\left[k_{i j}\right]\right)=s_{L 0} \min _{v \in S}\left\{\frac{P_{F U E I} f(v, 0)+F}{v}\right\}
$$

(boundary condition: ship returning to home port)

\footnotetext{
${ }^{9}$ This should be at least one order of magnitude greater than the maximum possible value of $\mathrm{V}$. Setting it to $\$ 1$ billion should be adequate.
} 
If $R \neq \varnothing$,

then $V\left(L,\left[k_{i j}\right]\right)=\left\{\begin{array}{l}M \text { if } w>Q \\ \min _{(x, y) \in R}\left\{S_{L_{U}} \cdot C^{*}+\lambda d_{x y}(\alpha u+\beta w)+V\left(L,\left[\dot{k_{i j}}\right]\right)\right\} \text { otherwise }\end{array}\right.$

where $C^{*}$ is the optimal value of the optimization problem defined by

$C^{*}=\min _{v \in S}\left\{\frac{P_{F U 日} f(v, w)+\alpha u+\beta w+F}{v}\right\}$

with $S=\left\{v: v_{L B}(w) \leq v \leq v_{U B}(w)\right\}$

In the above recursion,

$u=\sum_{(i, j) k_{\bar{i}}=3} d_{i j}$
$w=\sum_{(i, j) k_{\bar{q}}=2} d_{i j}$

$\lambda d_{x y}$ is the port dwell time,

and for all pairs $(i, j)$ with $i \neq j$, it is:

$k_{\bar{i}}^{\prime}=\left\{\begin{array}{l}k_{i \bar{j}}-1 \text { if } i=x \text { and } j=y \\ k_{i j} \text { otherwise }\end{array}\right.$

$\dot{L}= \begin{cases}x & \text { if } k_{x y}=3 \\ y & \text { if } k_{x y}=2\end{cases}$

To solve the problem, the recursion is executed backwards, by lexicographic ordering of the state variable vector and solving by moving to lexicographically increasing states. An alternative is to solve the recursion stage by stage, by defining an appropriate stage variable $\mathrm{m}$ as follows:

Ship is at port 0 (start), $m=0$

Ship is port 0 (end), $m=2 n(n-1)+1$

Ship is at any intermediate port, $m=3 n(n-1)-\sum_{(\mathrm{i}, \mathrm{j}): ; \neq \mathrm{j}} \mathrm{k}_{\mathrm{ij}}$

The stage-by-stage method is computationally more cumbersome than the lexicographic approach (in which $m$ is not necessary) and as a result we have not used it. The algorithm was coded in Fortran 95 and implemented on a PC.

As in Psaraftis (2011), the computational effort of this method is as follows. Regarding memory, $L$ grows as $\mathrm{O}(n)$, and the number of possible combinations 
of values of the $[k]$ matrix is $O\left(3^{r}\right)$, where $r$ is the number of non-zero O/D pairs, hence memory grows as $\mathrm{O}\left(n 3^{r}\right)$. For a complete graph, $r=n(n-1)$. Each iteration of the recursion takes $\mathrm{O}(r)$ time, bringing the total computational effort to $\mathrm{O}\left(r^{2} 3^{r}\right)$. This can be as high as $\mathrm{O}\left(n^{4} 3^{\text {n2 }}\right)$ in the most general case. An exception is if both $\alpha$ and $\beta$ are zero, in which case there are no summations to be taken. In this case the computational effort reduces to $\mathrm{O}\left(n^{2} 3^{r}\right)$.

It can be seen that it is mainly $r$, the number of cargoes, rather than $n$, the number of ports, that dictates computational effort. Obviously such effort is on the high side for anything but small values of $r$, especially if matrix $[d]$ is complete. Lower computational times can be achieved in special cases, for instance in sparse graphs or for low values of $Q$.

\section{Extensions}

The following extensions should be straighforward to implement:

1. Include cargo handling costs: Assuming that these are proportional to port dwell time, one can add a term equal to $C_{p} \lambda d_{x y}$ within the large bracket in recursion (1), where $C_{p}$ is the per unit time cargo handling cost. However, as total port dwell time is proportional to total cargo volume and therefore fixed, adding this cost component will not change the optimal solution.

2. Include per call port costs: If there is a fixed component to port cost, say a per call cost of $C C_{K}$, then one can add this term within the large bracket in recursion (1), but only whenever $L^{\prime} \neq L$, in the sense that this cost is accounted for only if the state transition involves moving from port to port. If $L^{\prime}=L$, the state transition involves loading or unloading cargo and this cost should not be accounted for.

3. Include different loading and unloading rates $\lambda$, different cargo handling costs $C_{p}$ and different per port call costs $C C_{K}$ at each port.

4. Include different inventory coefficients $\alpha$ and $\beta$ for each cargo, if for instance the cargoes have different values.

5. Last but not least, one can even include different fuel consumption functions for different legs of the route, say, due to different average weather conditions, sea currents, etc. 